\title{
Capital market offenses in Malaysia
}

Article

Accepted Version

Kan, Y. Y. (2018) Capital market offenses in Malaysia. Qualitative Research in Financial Markets, 10 (2). pp. 171-188. ISSN 1755-4179 doi: https://doi.org/10.1108/QRFM-04-20170038 Available at https://centaur.reading.ac.uk/77249/

It is advisable to refer to the publisher's version if you intend to cite from the work. See Guidance on citing.

To link to this article DOI: http://dx.doi.org/10.1108/QRFM-04-2017-0038

Publisher: Emerald

All outputs in CentAUR are protected by Intellectual Property Rights law, including copyright law. Copyright and IPR is retained by the creators or other copyright holders. Terms and conditions for use of this material are defined in the End User Agreement.

\section{www.reading.ac.uk/centaur}

\section{CentAUR}

Central Archive at the University of Reading

Reading's research outputs online 


\title{
Capital Market Offenses in Malaysia
}

\author{
Yoke Yue Kan \\ University of Reading \\ y.y.kan@ reading.ac.uk
}

\begin{abstract}
Purpose - The objective of this study is to review and evaluate the salient features of stock market manipulation in Malaysia. The research questions used are: Who was involved? How it happened? What were the consequences?

Design/methodology/approach - This research paper has been conducted using content and thematic analysis. The study includes multiple sources of information to help establish the stylized facts and uses cases that have been prosecuted in Malaysia for the period 2005 to 2015. Findings - This paper presents arguments and empirical data supporting the view that the stock market manipulation was conducted by those in a privileged position and with access to information. Ethical failure involving greed, self-interest, dishonesty and a preoccupation with a quick profit, could explain why stock market manipulation happened. Manipulation harms legitimate investors as share prices and earnings of companies are affected.

Practical Implications - A better understanding about the prevalence, characteristics and consequences of the market manipulation problems will be useful for stakeholders, investors and policymakers in the financial industry to promote and maintain a fair, efficient and transparent stock market.

Originality/value - The originality of this paper lies in examining and presenting interpretations based on contemporary phenomenon within the real-life context of Malaysia. There is little study or literature that focuses on Malaysia, especially in examining stock market manipulation by integrating finance and management perspectives to form a comprehensive understanding of the issue.
\end{abstract}

Keywords Capital market, insider trading, Malaysia, stock market manipulation, offenses

Paper type Research paper 


\section{Introduction}

In recent years, Malaysia underwent a series of capital market offenses by listed companies. Stock market manipulation undermines investors' confidence and affects the smooth running of a fair and secure financial market. It is important to identify the key lessons of the recurring cases to understand why manipulation is prevalent in Malaysia.

The objective of this study is to review and evaluate the salient features of stock market manipulation in Malaysia based on empirical evidence. The research questions used are: Who was involved? How it happened? What were the consequences?

This research paper has been conducted using content and thematic analysis to identify, analyze and highlight themes or patterns within the data (Braun and Clarke, 2006). This study uses multiple sources of information for establishing the stylized facts of those cases that have been prosecuted in Malaysia. The sample period of 2005-2015 is selected based on data availability. All reported cases involving listed companies are included in the sample. In total, 33 cases on stock market manipulation are identified based on enforcement-related press releases by the Securities Commission Malaysia (SC).

This paper presents arguments and empirical data supporting the view that stock market manipulation was conducted by those in a privileged position and with access to information, at the expense of retail investors. Ethical failure involving greed, self-interest, dishonesty and a preoccupation with a quick profit, could explain why stock market manipulation happened. Manipulation harms legitimate investors as share prices and earnings of companies are affected. Weak and inefficient enforcement fails to deter the prevalence of stock market manipulations.

Market manipulation is detrimental to stock markets in general, although there is little empirical evidence supporting this concern in Malaysia. The originality of this paper lies in examining and presenting interpretations based on contemporary phenomenon within the reallife context of Malaysia. There is little study or literature that focuses on Malaysia, especially in examining stock market manipulation by integrating finance and management perspectives to form a comprehensive understanding of the issue. The findings of this study are relevant not only to Malaysia but also to other emerging stock markets.

It is hoped that investigating these cases will lead to a better understanding about the prevalence, characteristics and consequences of the problems. By capitalising on what has gone wrong and building on their awareness and knowledge, stakeholders can make informed decisions to help reduce occurrences of market manipulation in the future. The knowledge gained will be useful for practitioners and policymakers in the financial industry so that they can promote and maintain a fair, efficient and transparent stock market.

The remainder of the paper is organized as follows. Section 2 defines the key concepts and reviews the related literature on capital market offenses. Section 3 describes the methodologies used in the study. Section 4 presents the empirical findings and discusses the key characteristics and implications of the cases. The paper concludes by outlining lessons learned from the cases and offering some policy solutions. 


\section{Literature review}

This section defines the key concepts and reviews the major literature on stock market manipulation.

Stock market is an important source for raising long-term funds to finance economic activity. A stock market can be related to the exchange of information. A market serves as the platform or forum for the exchange of information about goods and services. "As securities can be seen as tokens of information on entitlements, securities markets are thus about the exchange of information about information" (Hansen, 2003). Information asymmetry occurs when one party to a transaction has more material and significant information to the transaction than the other party. The party with an informational deficit is likely to enter a transaction at a disadvantage and with risk. As such, it is important to prevent the disadvantageous impacts following from asymmetries of information. Informational aysmmetries may be addressed by an obligation to disclose, a ban on using any informational advantage, or by a ban on misinformation (Hansen, 2003).

There is no consensus or generally accepted definition of stock market manipulation. As a general term, stock market manipulation could cover a number of practices deemed harmful to the capital markets (Carroll, 2002). The Oxford Dictionary defines manipulation as, "to control or influence somebody, often in a dishonest way so that they do not realize it". Based on the Capital Markets and Services Act 2007 in Malaysia, stock market manipulation is defined as the act of transacting the securities of a corporation that are likely to have the effect of raising, lowering or maintaining the price of securities for the purpose of inducing other persons to acquire or dispose of the securities of the corporation or of a related corporation (Securities Commission Malaysia, 2015).

The types of conduct and the activities involved in stock market manipulation come in many forms, the number is limited only by human ingenuity (Carroll, 2002). Manipulation is possible and it occurs in a wide variety of markets and circumstances (Putnins, 2012). Stock market manipulation is expressed in various terms and classified in different ways in literature.

Allen \& Gale (1992) categorized manipulation techniques into three broad types: trade-based manipulation, information-based manipulation and action-based manipulation. Trade-based manipulation means influencing share prices through trading. Information-based manipulation encompasses the release of untrue information or misleading rumours about a company in order to inflate or decrease its price. Action-based manipulation involves actions to impact the value or perceived value of a stock. For example, to shut down a factory to depress the share price.

Putnins (2012) divided manipulation into: (i) runs, (ii) contract-based manipulation, and (iii) market power techniques.

(i) In a run, the manipulator first takes either a long or a short position in a stock. Then the manipulator would inflate or deflate the share prices by attracting liquidity to the stock using techniques such as rumour spreading, wash sales and pooling. A run that inflates a share price is referred to as "pump-and-dump", while the opposite is known as "Bear raids". The manipulator's position will be reversed when sufficient gain is made. The manipulator profits directly by exploiting investors who buy at 
inflated prices or sell at depressed prices. The manipulation process can take anywhere from a matter of hours to several years.

(ii)

In contract-based manipulation, the manipulator profits from a contract or market, such as derivatives, that is external to the manipulated market. Such manipulation does not require the manipulator to induce others to trade at manipulated prices and therefore tends to be more mechanical by nature.

(iii) Market power techniques involves taking a controlling position in the supply of a security to profit from exploitation of other market participants.

According to the Capital Markets and Services Act 2007 (Act 671) in Malaysia, there are eight categories of prohibited conducts in securities trading: (i) false trading (s. 175), (ii) market rigging transaction (s. 175), (iii) stock market manipulation (s. 176), (iv) false and misleading statements (s. 177), (v) fraudulently inducing persons to deal in securities (s. 178), (vi) use of manipulative and deceptive devices (s. 179), (vii) dissemination of information about illegal transactions (s. 181), (viii) insider trading (Securities Commission Malaysia, 2015).

False trading (also known as wash sale or market rigging) involves creating or causing a false or misleading appearance of active trading in securities. Such transactions involves the purchasing and selling of securities that do not involve a change in the beneficial ownership of those securities. Such fictitious transactions could maintain, increase, decrease or create volatility in share prices. A technique closely related to wash sales is matching orders or prearranged trading, this involves the entering of buy and sell orders of the same securities at the same time, size and price.

False or misleading statements involves disseminating information that is false, misleading or deceptive about a particular material. The term rumourtrage has a similar connotation and means spreading false or misleading rumours about company value in order to create artificial or false stock prices (Gerace et al., 2014). The types of information disseminated might include: statements, promises and forecasts, and even involve dishonest concealment of material facts. Such action is likely to have the effect of raising, lowering or maintaining the market price of securities. Such action is also likely to induce the sale or purchase of securities by other persons (known as fraudulent inducement dealing). The person making the statement either knows it is wrong, or should have known it was wrong, but did not care. This category includes the employment of manipulative and deceptive devices, schemes or artifice to defraud.

Insider trading involves the purchase or sale of securities by, or on behalf of, a person or party who has relevant and non-public material information regarding the stock. Such information may affect the price of the security if made public, and ordinary investors would want to know such information in any decision-making process. A person is an "insider" if that person possesses material information that is not generally available and has a material effect on the value of securities (Securities Commission Malaysia, 2015). At the policy level, insider trading is considered bad and should be banned. On the other hand, Manne (1966) defended insider trading as efficiency enhancing. Insider trading should be allowed since this is the most effective way to compensate insiders for generating new economic information to the stock market. Through trading, insiders communicate the unpublished material information to the stock market, which makes stock prices more informative and efficient and, in turn, promotes the optimal allocation of resources (Fischel and Carlton, 1983).

Stock market manipulation has negative consequences as market efficiency is disrupted when prices no longer reflect the market forces of demand and supply. Such actions can victimize 
individual investors and erode public confidence in market integrity. Empirical evidence shows that market manipulation is harmful.

Aggarwal and Wu (2006) examine 142 cases of stock market manipulation based on SEC litigation releases in the United States from 1990 to 2001. They find that manipulators were potentially informed parties, such as corporate insiders, brokers, underwriters, large shareholders and market makers. Most of the manipulation cases occurred in relatively inefficient markets, which were small and not liquid. During the manipulation period, liquidity, returns and volatility are higher for manipulated stocks than for the matched sample.

Crutchley et al. (2007) examine 97 firms under the investigation by the Securities and Exchange Commission for accounting fraud in United States between 1990 and 2003. The results show that the corporate environment most likely to lead to an accounting scandal, manifests significant growth and accounting practices that are already pushing the envelope of earnings smoothing. Scandals occur in companies when there is a lack of sufficient monitoring from boards and there is wealth incentive for fraud (Crutchley et al., 2007).

Gerace et al. (2014) study 40 cases of market manipulation from 1996 to 2009 that were successfully prosecuted by the Hong Kong Securities and Futures Commission. Manipulation was found to negatively impact on market efficiency when the bid-ask spread and volatility is used as measurement. Markets appeared incapable of efficiently responding to the presence of manipulators, who were successfully able to raise prices and exit the market (Gerace et al., 2014).

Huang (2015) finds that the Chinese stock market was plagued with market manipulation, insider trading, IPO fraud and other securities irregularities due to lax regulation, ineffective supervision and institutional defects. This created room for power-money trading and lured potential offenders to loot huge profits from the majority of the public retail investors.

Wirama et al. (2017) examine the market manipulation in Indonesia and find that market rumors were intentionally published by sellers to attract buyers. Market-makers with larger capital and better access to information and media have the power to influence stock prices by publishing unsubstantiated information. Rumors were followed by statistically significant abnormal returns up to their third appearance, after which they began to lose their power to fool the market.

From the literature review several key conclusions can be drawn. Manipulation uses various techniques in a wide variety of markets and circumstances. Manipulation distorts prices and harms investors. This paper extends previous works on this topic by examining the capital market of a developing country, Malaysia, from 2005 to 2015. 


\section{Research methodology}

This research paper has been conducted using content and thematic analysis. Content analysis is a systematic and rigorous approach to analyze documents obtained in the course of the research (White \& Marsh, 2006). Thematic analysis is a method to identify, analyze and report themes or pattern within data (Braun and Clarke, 2006).

This study uses multiple sources of information for estabilishing the stylized facts based on cases that have been prosecuted in Malaysia. The sample period of 2005 to 2015 is selected based on data availability. All reported cases involving listed companies are included in the sample. In total, 33 cases on stock market manipulation are identified based on enforcementrelated press releases by the SC. The data is collected from provisions of statutes, reports on court cases, articles in the press and archival data, such as analysts' reports and company annual reports. The share prices and financial information is collected from Datastream. The use of multiple sources of information ensures the validity of the research through data triangulation and incorporating the different perspectives from various documents.

Data collection and analysis have been developed together as an iterative process, organized to answer the research questions: Who was involved? How it happened? What were the consequences? Data has been coded and categorized in a systematic fashion, relevant to the key themes as shown in Figure 1.

Figure 1 Key themes of the research

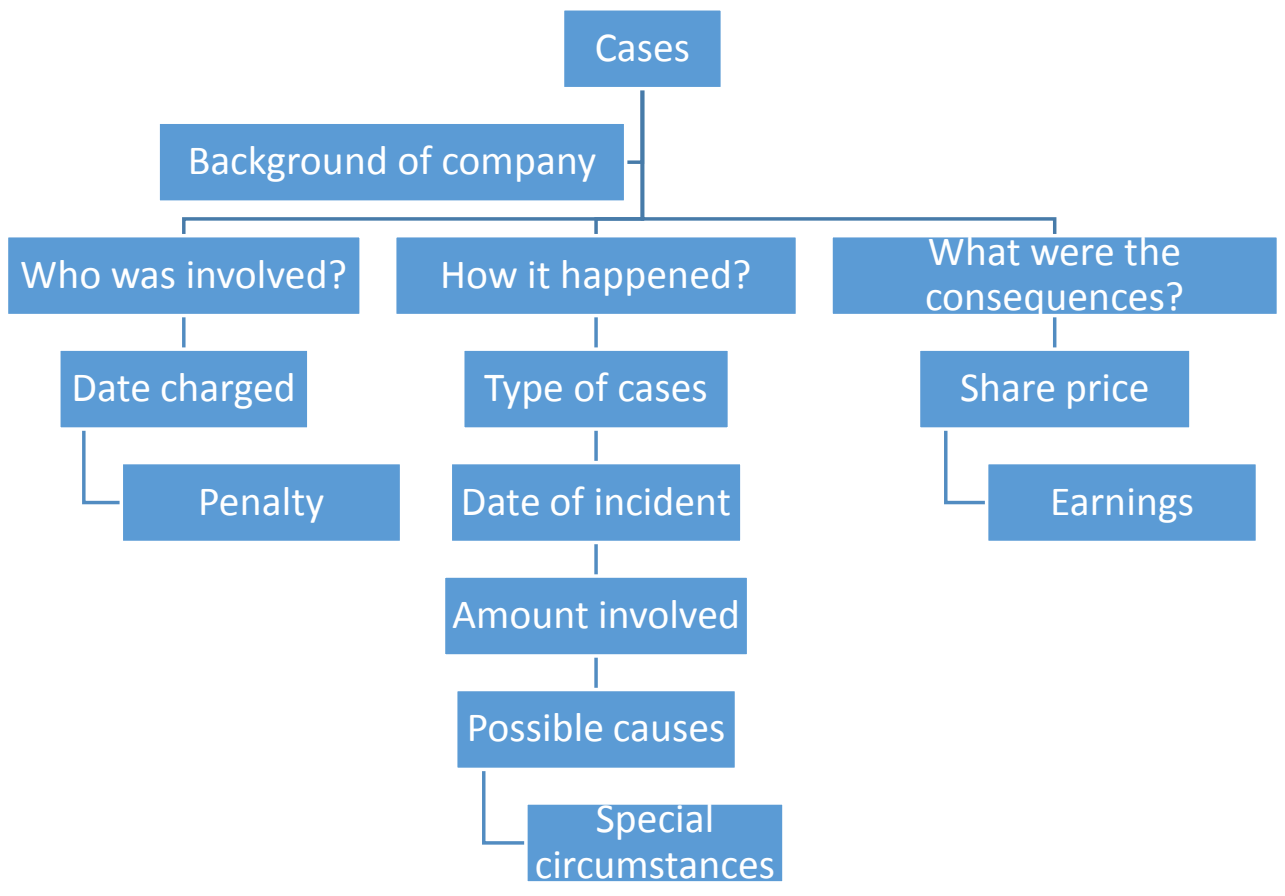

The data analysis included examining, categorizing and tabulating both quantitative and qualitative evidence to address the objective of the study - to uncover major characteristics, determine meanings and construct conclusions (Yin, 2003). An inductive approach is used to 
gain an understanding of the multifaceted aspects of the stock market manipulation cases. Content analysis assumes that groups of words reveal underlying themes. Co-occurrences of keywords can be interpreted as reflecting association between the underlying concepts (Duriau et al., 2007). The data analysis is also supported by basic descriptive statistics and two-sample hypothesis tests on mean and variance.

Based on the common themes across different cases and nine coded segments, some key lessons are identified. The interpretations and arguments are supported with empirical evidences that was synthesized from the commonalities of different cases. In addition, basic statistical techniques have been employed to support the argument and put them into context. The frequency of certain features is highlighted as it may indicate existence, intensity and relative importance (White and Marsh, 2006).

The benefits of thematic analysis includes the flexibility of analysis to answer particular research questions and apply to a broad range of organizational phenomena (Braun and Clarke, 2006; Duriau et al., 2007). Thematic analysis provides a detailed account of the data as both qualitative and quantitative data, and a wide range of analytical techniques can be employed to generate findings and put them into context (White and Marsh, 2006).

However, this study has several caveats to note about the findings. Similar to the study of Aggarwal and $\mathrm{Wu}$ (2006), only data for manipulation cases that have had enforcement action by the SC have been included. Therefore, this study does not include cases in which (i) manipulation is possible, (ii) manipulation happened but was not discovered, (iii) manipulation happened and was investigated by the SC but did not lead to any legal action. Therefore, the sample may reflect inexpert or poor manipulators as these were caught manipulating markets and received enforcement action, whereas others didn’t (Aggarwal and Wu, 2006).

A note on the interpretation of these cases is warranted. When this research was conducted, some of the court cases and charges were still on-going. Propositions in this study do not aim to pronounce any conclusions or judgments about facts and personal traits of individuals since the research is documented based on archival data. In general, case studies are constructed to explain the mechanisms contributing to the events but do not create any rule for prediction of future events (Wynn \& Williams, 2012). 


\section{Analysis and findings}

Based on the literature review, the manipulation activities have been classified into seven main categories. The most common type of capital market offense in Malaysia involved false information or misleading disclosure (13 cases), followed by trading manipulation ( 6 cases), insider trading (5 cases) and misappropriation of fund (5 cases). Other offenses committed include: unfair allocation of Initial Public Offering (IPO) and rights issue (2 cases), money laundering (1 case) and audit failure (1 case). Table 1 gives a brief overview of the type of offense and the name of the company involved.

Table 1 Type of offense and company involved

\begin{tabular}{|c|c|c|c|}
\hline & Name & Type & Date convicted \\
\hline 1 & APLI Industries Berhad & Insider Trading & The case is ongoing \\
\hline 2 & Axis Incorporation Berhad & False Accounting Statement & 10-Jul-17 \\
\hline 3 & Bestino Group Berhad & Money Laundering & The case is ongoing \\
\hline 4 & DVM Technology Berhad & Trading Manipulation & The case is ongoing \\
\hline 5 & Fountain View Development Berhad & Trading Manipulation & 5 -Feb-10 \\
\hline 6 & FTEC Resources Berhad & Misappropriation of Fund & 11-Nov-09 \\
\hline 7 & General Soil Engineering Holdings Berhad & False Accounting Statement & 26-Dec-08 \\
\hline 8 & Granasia Corporation Berhad & False Accounting Statement & 2-Mar-10 \\
\hline 9 & Hospitech Resources Berhad & False Accounting Statement & 23-Nov-06 \\
\hline 10 & Hwa Tai Industries Berhad & IPO Fraud & 16-Sep-06 \\
\hline 11 & Inix Technologies Berhad & False Accounting Statement & $22-A p r-15$ \\
\hline 12 & Iris Corporation Berhad & Trading Manipulation & The case is ongoing \\
\hline 13 & Kenmark Industries Corporation Berhad & Insider Trading & The case is ongoing \\
\hline 14 & Kiara Emas Asia Industries Berhad & Misappropriation of Fund & 10-Nov-09 \\
\hline 15 & LFE Corporation Berhad & False Accounting Statement & $10-$ Oct-12 \\
\hline 16 & Lii Hen Industries Berhad & Trading Manipulation & The case is ongoing \\
\hline 17 & Liqua Health Corporation Berhad & Misappropriation of Fund & The case is ongoing \\
\hline 18 & Malaysia Pacific Corporation Berhad & Insider Trading & The case is ongoing \\
\hline 19 & Megan Media Holdings Berhad & False Accounting Statement & 18-Aug-09 \\
\hline 20 & MEMS Technology Berhad & False Accounting Statement & 11-Jan-11 \\
\hline 21 & Multicode Electronic Industries (M) Berhad & Misappropriation of Fund & 22-Sep-11 \\
\hline 22 & Ocean Capital Berhad & False Accounting Statement & 16-Jan-06 \\
\hline 23 & Pancaran Ikrab Berhad & Misappropriation of Fund & 5 -Oct-10 \\
\hline 24 & Polymate Holdings Berhad & False Accounting Statement & 21-Oct-09 \\
\hline 25 & Ranhill Power Berhad & Insider Trading & The case is ongoing \\
\hline 26 & Repco Holding Berhad & Trading Manipulation & 11-Jan-16 \\
\hline 27 & Silverbird Group Berhad & Audit Failure & 27-Jan-16 \\
\hline 28 & Suremax Group Berhad & Trading Manipulation & 7-Jan-11 \\
\hline 29 & Transmile Group Berhad & False Accounting Statement & 28-Oct-11 \\
\hline 30 & Transocean Holdings Berhad & Insider Trading & The case is ongoing \\
\hline 31 & United U-Li Corporation Berhad & False Accounting Statement & $21-$ Oct-15 \\
\hline 32 & UPA Corporation Berhad & IPO Fraud & 23-Apr-10 \\
\hline 33 & Welli Multi Corporation Berhad & False Accounting Statement & 1-Dec-10 \\
\hline
\end{tabular}

The following sections discuss the salient features of the cases and present the empirical data supporting the key arguments. 


\subsection{The misuse of privileges in position}

The perpetrators of capital market offenses are found to be people who are in a privileged position with access to information. As show in Figure 2, insiders and outsiders were involved in varying degrees. The offenders include: directors, finance officers, executive officers and a company's staff and auditors. Drawing from the statistics, showing 57\% (52 cases) of the offenders were directors, it can be argued that they misused their position and company information. The offenses were committed within the confines of positions of trust in the organizations. In one case the offender was well respected, for example, as the commitee member of the Federation of Malaysia Manufacturers Association (New Straits Times, 2006). Therefore, status and a position within upper management bestowed power, information and, consequently, an opportunity to manipulate.

Figure 2 Capital market offenders 2005-2015

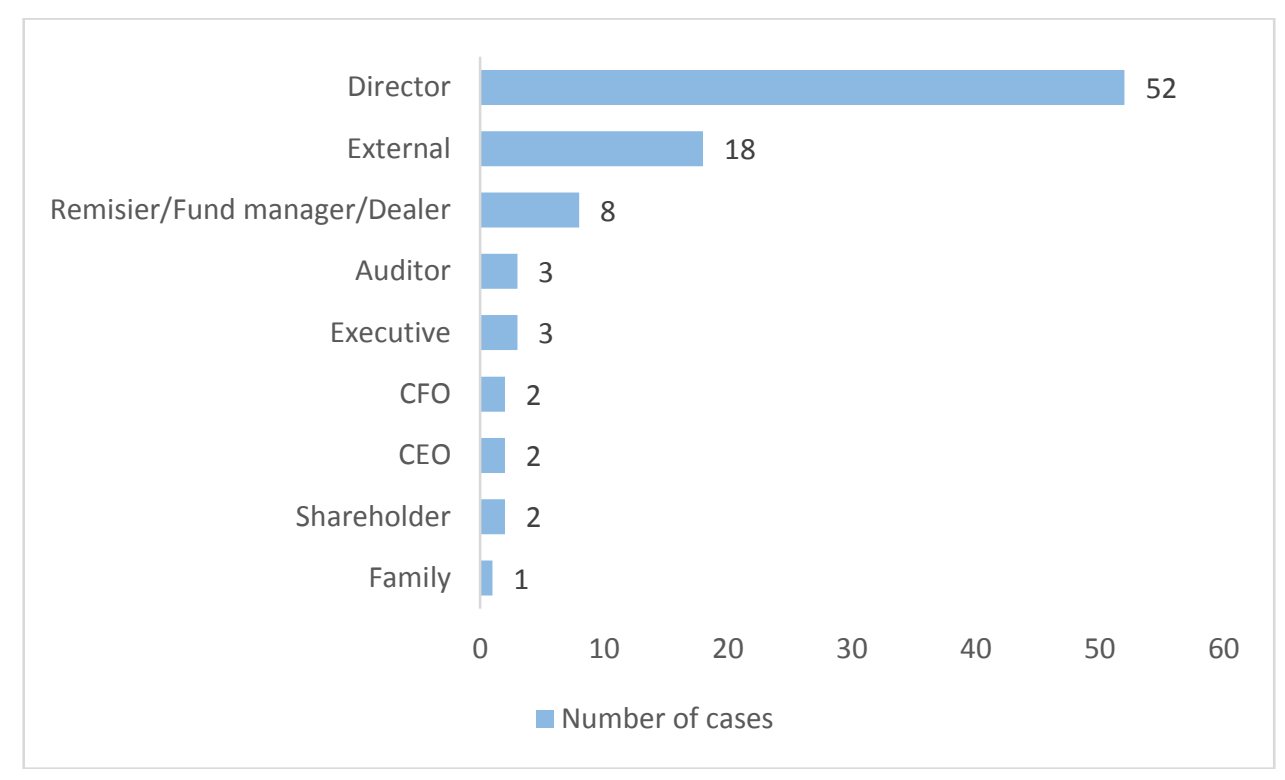

People with privileged information may include external staff who are indirectly involved in dealings. The case of UPA Corporation lends support to this notion. In this case, Ashari Bin Rahmat, the Operation Manager of Malaysian Issuing House, worked together with Fauzi Bin Ibrahim, to cheat UPA Corporation by switching 80 successfully balloted applications for its initial public offering with those that were not put through the balloting process. Fauzi misled UPA Corporation into believing that some 80 applicants had applied for its IPO shares when in fact he was the beneficial owner of all the applications. Both offenders pleaded guilty.

There are extraordinary situations that involve an outsider, as in the case of Kenmark Industrial Corporation. The issue emerged when Kenmark's major shareholder, James Hwang Ding Kuo, a Taiwanese with an $8.41 \%$ stake disappeared and subsequently sold his shares. The share price decreased in June 2010, reaching a low of 26 sen on 4 June 2010. The shares were purchased at a low price by an external party, Datuk Ishak Ismail up to $32 \%$ ownership (58.7 million shares), who subsequently sold off the shares (Fernandez, 2010). On 16 June 2010, the SC commenced civil proceedings and obtained an injunction against Datuk Ishak in order to restrain him from dealing with the proceeds of the RM10.2 million from his disposal of 
Kenmark shares. The proceeds from sales of shares were frozen while pending the outcome of the SC's civil proceedings against Datuk Ishak. The SC also obtained an order that required Datuk Ishak to furnish complete details of his assets, both locally and abroad, within four days of the order. In the civil proceedings against Datuk Ishak, the SC alleged that Datuk Ishak committed insider trading and made false or misleading statements (Securities Commission Malaysia, 2016).

\subsection{Trading on insider information}

For the cases in Malaysia, trading on non-public information commonly involved mergers, acquisitions, earnings, financial losses. Those with inside information and special access took unfair advantage of the general investing public. Such information was selectively communicated to directors, top management, accountants, brokers and family members. Insiders failed to prevent the transfer and misuse of non-public information to others close to them. Trading was conducted through related party accounts and large trade orders were executed. Such activity led to short-term profits but public investors suffered from the consequences.

For example, the case of Ranhill Power Berhad involved the trading of non-public information related to the privatization and de-listing of the company. The former director of Ranhill was charged for acquiring 309,100 shares through an external party account in 2007 . The director of Transocean Holdings Berhad was charged for acquiring 632,700 shares in 2009 whilst in possession of non-public information related to the proposed take-over offer by Kumpulan Kendaraan Malaysia Berhad.

The use of insider information allowed insiders to buy on good news or sell on bad news ahead of the market. Those with special inside information also took advantage of access to positive news. For example, the former CEO of Malaysia Pacific Corporation Berhad was charged with insider trading by acquiring shares ahead of entering into a multi-million ringgit joint venture project in Iskandar Development Region in Johor in 2008. On the other hand, trading on nonpublic information bad news happened before the news reached the public investors. For example, the executive director of APL Industries was charged for communicating non-public information related to audit adjustments on higher losses to dealer and family members. In the case of Kenmark Industrial, the trading on insider news involved the disappearance of a major shareholder.

\subsection{Distorted initial high prices}

Manipulation and fraud led to artificial and misleading stock prices and caused losses to public investors. The findings show that returns and volatility are higher for manipulated stocks during the manipulation period. Stock prices generally rose during the manipulation period and then fell in the post manipulation period. For example, MEMS Technology was traded at P/E ratio of 74 times in 2007 in the year when manipulation occured and EPS turned to negative in the subsequent years.

Fundamental valuation, such as PE ratio, cannot be used to justified the high share prices as most of these companies had negative EPS. The companies that were in loss when share price rose sharply included: APL, Axis, Fountain View, Liqua Health, Ocean, Suremax and 
Transmile. The majority of manipulation cases involved attempts to inflate the share price rather than to decrease the stock price. A possible explanation for this is the short-selling restrictions in Malaysia make it difficult for downward price manipulation.

For example, the false trading case of Repco Holdings Berhad involved substantial volatility in share price movement. Repco's share price hit a record of RM140.50 per share in August 1997 and dropped to RM7.10 a share when the stock was suspended in October 2000 (Koon, 2004). The former executive chairman created a misleading picture about the price of Repco shares on 3 December 1997. He instructed a dealer's representative of Sime Securities to buy Repco shares by taking up any offer price by sellers on the stock exchange. The act of manipulating shares was conducted over one day (3 December 1997) in one trading account (Khairah, 2016), with a purchase order of 227,000 Repco shares (Securities Commission Malaysia, 2016).

\subsection{Unusual volumes}

Trading manipulation created a false and misleading appearance of active trading. This resulted in a surge in volume. For example, the trading volume of DVM Technology shares increased to 63 million shares on 20 March 2006, compared to 3.6 million shares one week prior to the manipulation. Investigation by the Securities Commission revealed that the defendants didn't trade in DVM shares prior to the manipulation period. In another case, involving market rigging in Iris Corporation Berhad, an average of 200 million shares were traded daily from September 2005 to May 2006. The manipulation was conducted through a complex layering of the origination of the orders and transactions via foreign intermediaries. The perpetrators collectively used numerous trading accounts to create an artificially strong demand for Iris shares.

Trading volume can be artificially increased by the sale and purchase of shares that do not result in any change of beneficial ownership. For example, in the case of Lii Hen Industries, trading was executed through 42 accounts at nine stockbroking companies between March 2004 and October 2004. The major shareholder of Fountain View, Dato Chin Chan Leong, traded through at least 20 accounts which were beneficially owned by him through the companies that he controlled.

Trading manipulation creates a misleading appearance of active trading that does not result in any change of beneficial ownership. The modus operandi involved trading through many trading accounts at various stockbroking companies, which made detection difficult (Table 2). For instance, the manipulation of Suremax's shares was committed by executing buy and sell transactions through 153 trading accounts, across 12 stockbroking firms. In addition, the dealers were involved in abetting such trading manipulation. The sophistication of manipulation techniques has increased over time, as in the case of Iris Corporation Berhad, where trading was carried out through complex layering of the origination of the orders and transactions via foreign intermediaries. 


\begin{tabular}{|l|c|}
\hline Company & $\begin{array}{c}\text { Number of trading accounts } \\
\text { involved }\end{array}$ \\
\hline Suremax Group Berhad & 153 \\
\hline Lii Hen Industries Berhad & 42 \\
\hline Fountain View Development Berhad & 20 \\
\hline Repco Holdings Berhad & 1 \\
\hline
\end{tabular}

\subsection{Huge losses at price reversal}

Manipulators harmed legitimate investors who transacted at distorted levels that did not reflect corporate value. Table 3 highlights the top five highest losses in market capitalization of the companies involved in market manipulation activities. The statistics are based on the ranking of 18 sample companies as financial data of certain companies are no longer available after delisting. It is undeniable that the manipulation led to substantial loss to minority shareholders and public investors, who were least prepared for the risk and volatility in share price.

Table 3 Loss in market capitalization

\begin{tabular}{|c|c|c|c|}
\hline & & $\begin{array}{c}\text { Annualized percentage } \\
\text { change in share price in the } \\
\text { year when manipulation } \\
\text { occurred }\end{array}$ & $\begin{array}{c}\text { Market } \\
\text { capitalization } \\
\text { losses } \\
\text { (RM million) }\end{array}$ \\
\hline 1 & Transmile & $-44 \%$ & 3384.92 \\
\hline 2 & Fountain View & $-50 \%$ & 2179.88 \\
\hline 3 & Iris & $-94 \%$ & 1644.36 \\
\hline 4 & MEMS & $-90 \%$ & 362.04 \\
\hline 5 & Lii Hen & $-100 \%$ & 319.32 \\
\hline
\end{tabular}

Share price could react immediately and decline sharply in the short term, as in the case of Kenmark, which dropped 93\% in seven days (from RM0.83 on 25 May 2010 to RM0.06 on 1 June 2010). Investors holding these shares could suddenly see their fortune wiped out in mere days or weeks. For example, in 2005 Fountain View share prices dropped from RM5 level to RM0.40 within three weeks, wiping out more than RM1.8 billion in market capitalization. As a result, the investment of RM20 million in Fountain View Development Berhad by Selangor Turf Club registered a loss of RM16 million (Go and Neil, 2005). Subsequent decline in the share price could last for years. The longest duration of decline was Transocean, which declined by an annualized rate of $28 \%$ over 2.5 years. The downward trends showed that market sentiment and the confidence of equity investors were dampened by the fraud cases. The value of reputational capital is actually reflected in current stock prices.

To analyze and compare the impact of the offences on the return-risk profile of stocks, the Kuala Lumpur Composite Index (KLCI) from 2005 to 2015 is used as benchmark to represent the overall long-term market performance. The average annualized return of the sample stocks 
involved in manipulation are higher at $96.98 \%$, as compared to the long-term (10 years) annual return of KLCI of $6.19 \%$. The return of the sample stocks one month after the manipulation period show a annualized return of $-55.08 \%$, indicating substantial losses experienced by investors who did not manage to sell when the inflated share prices began to reverse. The volatility were high during the manipulation period, as well as during the one-month period after the manipulation, at annualized standard deviation of $111.45 \%$ and $168.04 \%$ respectively (Table 4).

Table 4 Comparison of Return and Standard Deviation of Return

\begin{tabular}{|l|c|c|c|}
\hline & $\begin{array}{c}\text { During } \\
\text { Manipulation }\end{array}$ & $\begin{array}{c}\text { 1 month after the } \\
\text { manipulation period }\end{array}$ & $\begin{array}{c}\text { Benchmark KLCI } \\
\mathbf{2 0 0 5 - 2 0 1 5}\end{array}$ \\
\hline Average Daily Return & $0.38 \%$ & $-0.22 \%$ & $0.02 \%$ \\
\hline Average Annualized return & $96.98 \%$ & $-55.08 \%$ & $6.19 \%$ \\
\hline $\begin{array}{l}\text { Average Daily Standard } \\
\text { deviation }\end{array}$ & $7.02 \%$ & $10.59 \%$ & $0.73 \%$ \\
\hline $\begin{array}{l}\text { Average Annualized } \\
\text { standard deviation }\end{array}$ & $111.45 \%$ & $168.04 \%$ & $11.63 \%$ \\
\hline
\end{tabular}

(Source: Datastream and author's calculation)

To compare the impact of manipulation, the two-sample hypothesis tests are conducted using t-test for difference in mean and F-test for difference in variance against the benchmark KLCI at $5 \%$ level of significance. The results show that the volatilities were statistically different from the long-term volatility of the market when manipulation occurred. Based on t-test on mean with unequal variance, the mean return when manipulation occurred was significantly higher than the benchmark index. Manipulation has benefited the perpetrators to gain abnormal return and created extreme risk in the market.

Listed companies stand to lose more than their reputation when market manipulation activities occur. The business and profitability were also affected after these companies were charged. Statistics show that $89 \%$ of the sample companies had negative EPS in the following financial year after the manipulation cases were reported. Some of these companies have been downgraded to PN17 status ${ }^{1}$, some are delisted from the stock exchange. For example, Repco Holding Berhad was delisted on 11 August 2003, Axis Corporation Berhad was delisted on 30 November 2010.

\subsection{Greed and dishonesty}

In general, ethical failure involving greed, self-interest, dishonesty and a pre-occupation with a quick profit could explain why stock market manipulation has happened. This is evidenced in the misappropriation of a company's fund. The amount of funds misappropriated can be

\footnotetext{
${ }^{1}$ PN17 stands for Practice Note 17/2005 and is issued by Bursa Malaysia. Companies that fall within the definition of PN17 are in financial distress and will need to submit their proposal for restructuring and reviving the company in order to maintain the listing status.
} 
substantial, reaching millions of ringgit (Figure 3). The highest amount misappropriated to date is RM37 million, which happened to Pancaran Ikrab.

Figure 3 Amount of fund misappropriated

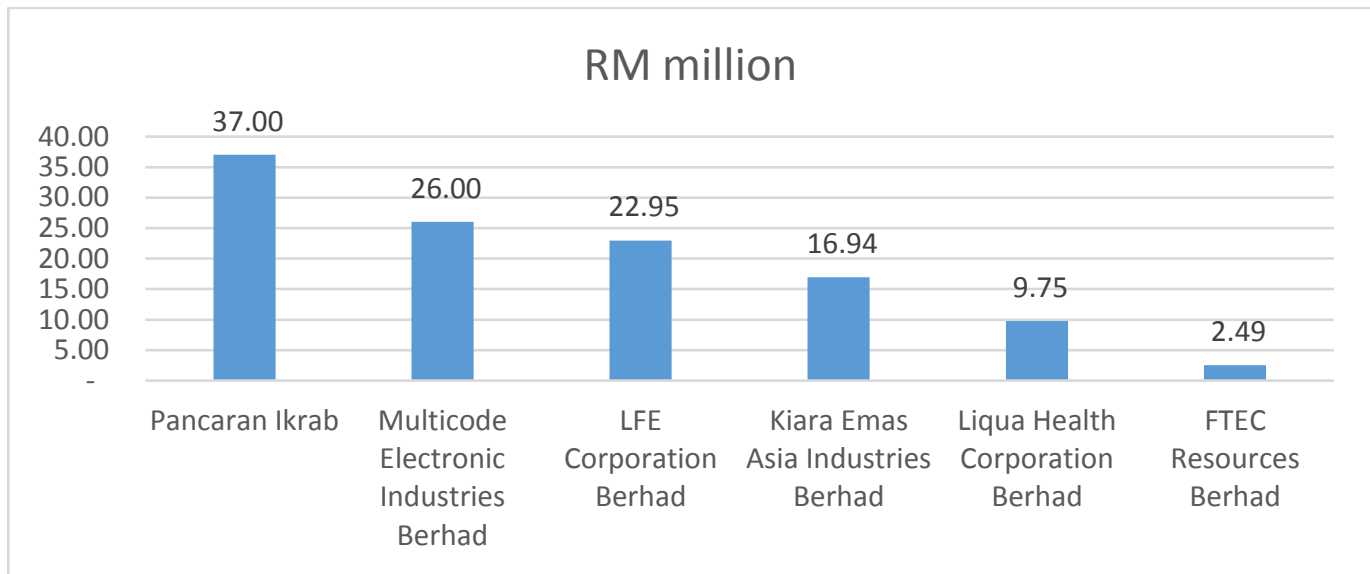

Dishonesty and the act of misleading investors by furnishing false statements to Bursa Malaysia were serious. The amount involved in the false accounting statement was substantial, registering a record high of RM1 billion (Table 5). Shareholders with substantial holdings were obssessed with share price movement, which is perceived to be related to earnings growth. Expectation on management to fulfil monthly and annual profit targets led to the falsification of accounting figures. In the case of Megan Media, the personal assistant to the executive chairman created fictitious invoices to support the false revenue of over RM1 billion. Such action benefitted the fraudsters. Several financial institutions were also deceived into providing trade facilities to Megan Media.

Table 5 Amount involved in false statement

\begin{tabular}{|l|c|}
\hline Company & RM million \\
\hline Megan Media Holdings Berhad & $1,000.00$ \\
\hline Transmile Group Berhad & 981.00 \\
\hline Welli Multi Corporation Berhad & 141.00 \\
\hline MEMS Technology Berhad & 73.42 \\
\hline Granasia Corporation Berhad & 27.36 \\
\hline Polymate Holdings Berhad & 22.74 \\
\hline Ocean Capital Berhad & 7.78 \\
\hline General Soil Engineering Holdings Berhad & 2.50 \\
\hline GP Ocean Berhad & 0.36 \\
\hline
\end{tabular}

The case of United U-Li Corporation Berhad was the first where the SC charged an outsider, a licensed audit partner, for abetting a listed company in submitting a misleading financial report to Bursa Malaysia. United U-Li's profit before tax for the financial year ended 31 December 
2004 was inflated by approximately $26 \%$. The auditor was sentenced to a one-year jail term and a fine of RM400,000.

Share price manipulation can occur right after listing of the initial public offering, as in the case of FTEC Resources Berhad. When the stock was listed on 19 December 2003, the initial public offering price was 45 sen. The share price rose to a record high of RM2.57 on 13 January 2004, an increase of $471 \%$ in 16 trading sessions, within less than a month after listing. At the height of the share price, FTEC was trading at a PE ratio of 200 times and a market capitalization of RM436.9 million, when its half-year profit was only RM1.375 million (Tam, 2004). The share price could not be explained by fundamental analysis as the company posted a net income of RM2.9million on a RM71.9 million turnover for the nine months to 30 September 2003. In the next four days, FTEC dropped sharply by $57 \%$ to RM1.11. When asked by the stock exchange about the unusual trading interest, FTEC replied that there was no material development in its business, but there was negotiation around a possible investment in a company. According to news reports, dealers said the selldown was due to operators cashing out after pushing up the prices (Raj, 2004). The misuse was not discovered earlier despite checks by the audit committee (Zaidi, 2007; Nambiar, 2007; The Business Times, 2004).

\subsection{Concentration on small capitalization}

The manipulation cases generally occured in companies with small capitalization, which are commonly known as penny stocks. The statistics show that the average market capitalization is RM177.12 million, with the largest market capitalization standing at RM3,415.10 million. These penny stocks often did not receive appropriate analyst coverage. Thus, trading manipulation may happen when retail investors do not have good knowledge about the companies and do not study the fundamentals or financial reports of the companies. These investors tend to use "buy on rumour, sell on news" strategies. 


\subsection{Weak enforcement}

In Malaysia, there are positive regulatory framework to promote a fair and secure market. Nevertheless, incidents of fraud cannot be curbed fully. In general, regulators faced challenges to implement an effective enforcement programs that is supported by adequate resources, supportive legal environment and political will.

At present, there are seven major entities related to the governance of listed companies in Malaysia:

- The Securities Commission Malaysia (SC) is a statutory body that has investigation and enforcement power in regulating all matters relating to securities and derivatives contracts. SC can take criminal and civil sanctions against offenders of securities crimes.

- Bursa Malaysia Securities Berhad is the stock exchange of Malaysia responsible for regulating and enforcing listing requirements such as immediate disclosure of material information, corporate restructuring, related-party transactions, share buy-backs, dealing by directors and principal offices. Bursa Malaysia has issued Corporate Governance Guide ${ }^{2}$ to support the board and management of listed companies through the structuring and implementation of sound practices and effective processes.

- The Companies Commission of Malaysia (CCM) is a regulatory body that register the incorporation of companies and provides business information to the public. It plays a role in ensuring compliance with business and corporate legislation by using enforcement and monitoring activities.

- The Malaysia Institute of Accountants (MIA) plays a role in setting reporting standard, conducting practice reviews to determine if professional standards have been applied. It also sets ethical standards for professional accountants.

- The Audit Oversight Board oversees the audit practice of public interest entities to ensure reliability of audited financial statements in Malaysia. The auditors of public interest entities are registered to ensure only fit and proper auditors are engaged in the auditing of financial statements.

- The Institute of Internal Auditor Malaysia is a non-profit organization dedicated to the advancement and development of the internal audit profession in Malaysia. It puts in place quality assurance procedures to enhance the quality of work performed by internal auditors.

- The Minority Shareholder Watchdog Group (MSWG) is a non-profit organization that protects the interest of minority shareholders through collective shareholder activism. It monitors non-compliance in corporate governance practices, breach of rules and regulations, as well as questionable practices by management of public listed companies. The organization may initiate reports to regulatory authorities where appropriate.

The number of cases of capital market offenses being charged is relatively low, compared to the number of unusual market activities reported. Unusual market activity involves a substantial rise or fall in share price over a short period of time, that can not be explained by fundamentals and with no information publicly available that can account for the activity. Unusual market activity could signify trading by persons who are acting on unannounced

\footnotetext{
${ }^{2}$ First issued in 30 June 2009, second edition issued in 1 October 2013.
} 
material information and could even be an indicator of market manipulation. It can mislead the investors to assume that the sudden change in price reflects a corresponding change in the business prospects of the underlying stock. Figure 4 shows that the irregular price movement and query by Bursa Malaysia on unusual market activity were high in comparison to the number of manipulations discovered.

Figure 4 Unusual market activities in Malaysia

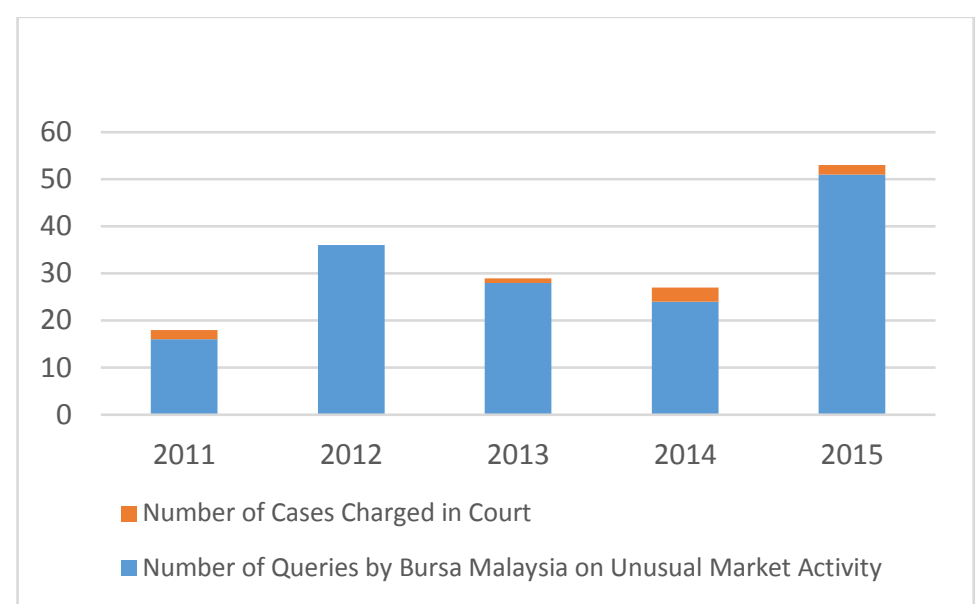

(Source: Bursa Malaysia's website and author's calculation)

It is also worth noting that market manipulation cases took place over a long period before being discovered. The cases were typically complex, difficult to investigate and prosecute, as evidenced by the few prosecutions achieved relative to the amount of unusual market trading activity. For example, the longest duration was the case of Repco Holding Berhad; the offense happened in 1997 and the director was convicted in 2016, after close to 19 years. Figure 5 gives an overview of the length of time taken to convict a case. 


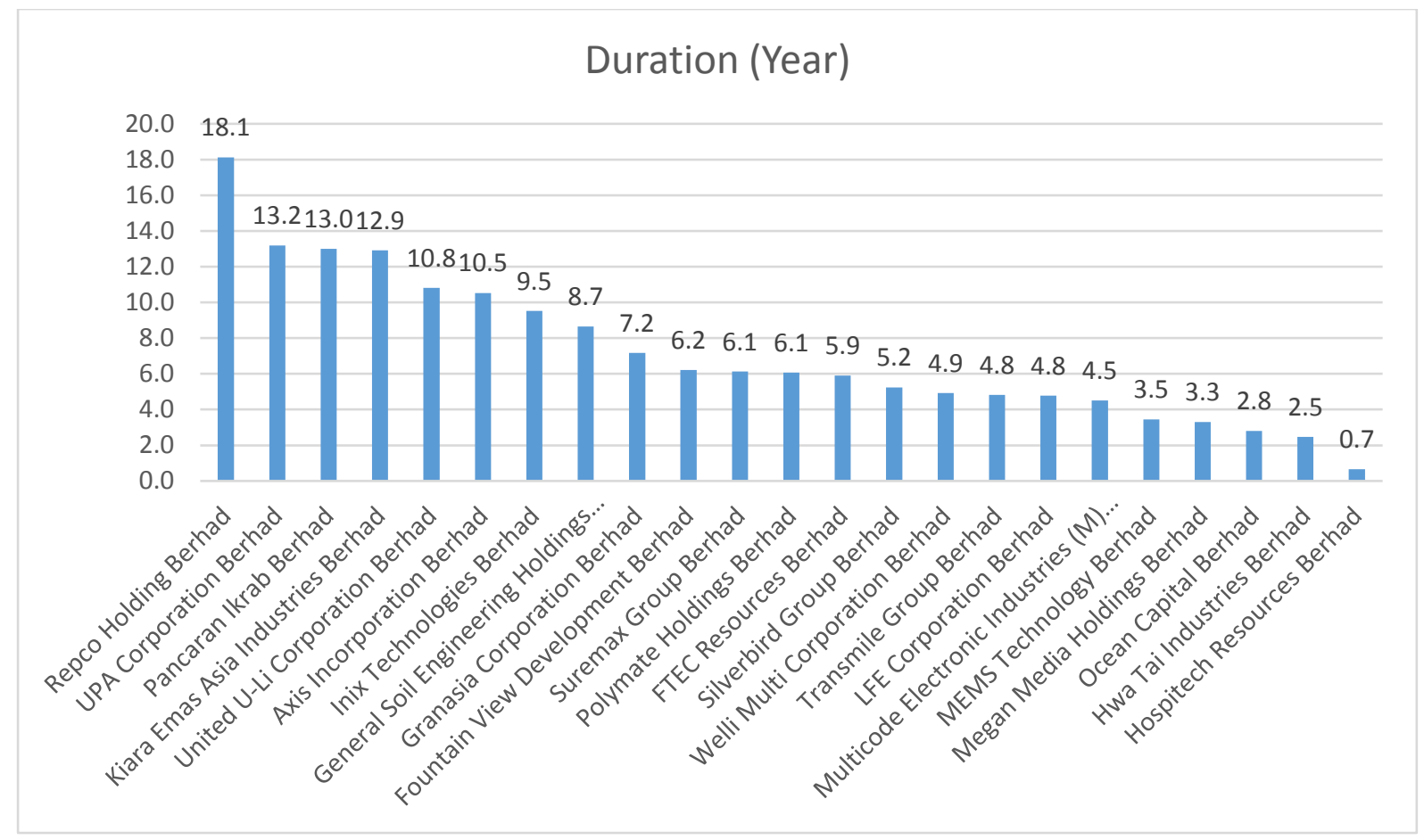

Evidence of weak enforcement can be found in various news articles. For example, it was reported that in 2005 the then Prime Minister of Malaysia, Datuk Seri Abdullah Ahmad Badawi, was concerned about unusual market activities and directed the SC to speed up its investigation into alleged manipulation of share prices, giving them a one-month deadline to produce results (New Straits Times, 2005). Based on news report, between 2003 and 2013, the SC charged 13 people for committing or abetting in insider trading; only three individuals were prosecuted (Oh, 2015).

The cases have also demonstrated poor internal regulatory practices. Civil settlements fall short of true reimbursement. The Capital Markets and Services Act 2007 (CMSA) can impose a prison sentence of up to ten years or a fine of up to MYR 5 million for breaches. Based on historical sentences, falsification of financial statements led to fines ranging from RM150,000 to RM500,000. The most severe sentence recorded was when the former executive chairman of Repco was sentenced to five years imprisonment and a fine of RM5 million on 11 January 2016. This sentence is the longest prison term imposed by the courts in a market manipulation case to date.

However, the amounts defrauded are often many times more than the fines. The perpetrators get away with far less, in terms of sentences, compared to the millions of ringgit defrauded ${ }^{3}$. For example, in the case of Pancaran, the offender was sentenced to a one-day imprisonment and a total fine of RM2 million. In October 1997, the offender used RM15.5 million of Pancaran funds to finance his entry into the company and to finance his purchase of the

\footnotetext{
${ }^{3}$ Examples include Kiara Emas, LFE Corporation, Multicode, Pancaran Ikrab.
} 
controlling shareholding in Pancaran. When he resumed his post as director of Pancaran, he transferred RM37 million out of the company. This amount was never recovered and was written off in its accounts. It is very clear that the sentence was light for the massive RM52.5 million that was defrauded. The court even allowed the offender to pay the fine in 12 instalments (Gunasegaram, 2010).

\section{Implications and conclusion}

This analysis on stock market manipulation points to some important lessons. The following section discusses the important implications and provides suggestions about how capital market offenses can be minimized or prevented.

Good corporate governance plays an important role in underpinning the integrity of the capital market. This is because good corporate governance reflects a company's commitment to values, ethical business conduct, and good practice in disclosure and control systems. Corporation should be run for the benefits of all stakeholders, not just the shareholders. The role of the board of directors is crucial to ensuring market integrity and continued investor confidence in the capital market. All directors must ensure that their fiduciary duties are discharged in a responsible and professional manner, and with high standards of diligence at all times. They must act in good faith and avoid any potential conflict of interest in any situation.

As many of the cases involved directors and top management, ethical leadership is important. An ethical leader should: act fairly, promote ethical conduct, allow different opinions and voices among staff, show concern, demonstrate integrity, maintain consistency and take responsibility for one's actions. Strong leadership is fundamental to achieving high standards of governance and to ensure fair dealing for all the stakeholders. The top managment of listed companies need to regularly emphasize the importance of business ethics and compliance with best practices.

In the case of insider trading, a company should make reasonable efforts to achieve public dissemination of the non-public information in an equitable manner. Information must only be communicated to designated supervisory staff who must not take investment action on the basis of the information. Listed companies need to adopt compliance procedures to prevent the misuse of non-public information. Disclosures and announcements serve as useful sources of information for the market participants. In addition, written compliance policies and guidelines should be circulated to all employees. Employees should be given sufficient training.

The huge losses and volatility caused by manipulation, the victimization of investors and the market as a whole provide strong rationale for jurisdiction. It is important to have effective laws and strong enforcement to prohibit manipulation. Higher penalties should be imposed on those who breach the laws as a deterrent to offend. Active monitoring by securities regulators is essential to prohibit market manipulation. Whenever there is sufficient evidence from unusual share price movement, quick and efficient investigations and actions should be taken. If the enforcement is ineffective or perceived to be ineffective, the ability of the regulatory bodies to achieve the desired outcome will be challenging.

Fair, timely and accurate disclosure of information is central to the principle of fair treatment of investors. Confidence in the capital market is sustainable when investors can trust the integrity of disclosure made by companies, especially in relation to the financial position. 
Accountants and accounting executives need to be aware of the importance in providing reliable, complete and accurate information to investors. They have the responsibility to prepare financial statements and disclosures in accordance with applicable, and approved, accounting standards and in compliance with the relevant rules and regulations. It is important for the audit committee to have members who are ready and prepared to engage in open dialogue on equal terms with the external and internal auditors, and with senior management. In addition, companies must conduct the required due diligence to ensure the accuracy and completeness of financial information.

Stock market manipulation cases show that it is essential for investor to consider the fundamentals and the credibility of the company when making investment decisions. It is noteworthy to highlight that when a company is involved in stock market manipulation and subsequently delisted from the stock exchange, important information such as share price data, trading volume, financial performance, financial reports, details of manipulation are removed from the stock exchange's public portal and no longer accessible by the public. It is highly recommended to maintain the information for public access and investor education purpose, so that the general public can learn from what has gone wrong in history.

These cases have brought ethical business questions to the forefront and show business schools and corporates the importance of ethics education. Understanding the value of ethical conduct and responsibility to other stakeholders is critical. Companies should have an independent ethics department, committee and officers, and they should conduct employee training, workshops and formal discussions on its ethical expectations. There should be zero tolerance to unethical and manipulative behaviors, even if such behaviors result in profitability for the corporation.

Lastly, all market participants have a fundamental role in upholding the integrity of the financial market. It is crucial to have a system of checks and balances; this may also include an evaluation by an independent party from outside of the company. It is also essential to encourage market participants to collaborate with authorities for investor protection, immediately alerting the SC if they become aware of any fraudulent issues. An anonymous channel for reporting unethical conduct is essential.

\section{References}

Aggarwal, R. \& Wu, G., 2006. Stock market manipulations. Journal of Business, 79(4), pp. 1915-1953.

Allen, F. \& Gale, D., 1992. Stock-price manipulation. The Review of Financial Studies, 5(3), pp. 503529.

Braun , V. \& Clarke, V., 2006. Using thematic analysis in psychology. Qualitative Research in Psychology, Volume 3, pp. 77-101.

Bursa Malaysia Berhad, 2013. Corporate governance guide: towards boardroom excellence. Kuala Lumpur: Bursa Malaysia Berhad.

Business Times, 2004. FTEC bucks downtrend. 5 February, p. 6.

Carroll, W. J., 2002. Market manipulation: an international comparison. Journal of Financial Crime, 9(4), pp. 300-307. 
Crutchley, C. E., Jensen, M. R. H. \& Marshall, B. B., 2007. Climate for scandal: corporate environments that contribute to accounting fraud. The Financial Review, Volume 42, pp. 53-73.

Duriau, V., Reger, R. \& Pfarrer, M., 2007. A content analysis of the content analysis literature in organization studies. Organizational Research Methods, 10(1), pp. 5-34.

Fernandez, F., 2010. Ishak makes exit from Kenmark. New Straits Times, 15 June.

Fischel, D. R. \& Carlton, D. W., 1983. The regulation of insider trading. Stanford Law Review, 35(1), pp. 857-895.

Gerace, D., Chew, C., Whittaker, C. \& Mazzola, P., 2014. Stock market manipulation on the Hong Kong Stock Exchange. Special Issue on Financial Planning \& Financial Instruments, 8(4), pp. 106-140.

Go, R. \& Neil, S., 2005. SLTC face RM16m loss. New Straits Times, 13 May, p. 48.

Gunasegaram, P., 2010. Too little punishment for too much. McClatchy - Tribune Business News, 9 October.

Hansen, J. L., 2003. The trinity of market regulation: disclosure, insider trading and market manipulation. International Journal of Disclosure and Governance, 1(1), pp. 82-96.

Huang, X., 2015. Scandal-driven regulation of China's stock market: dynamics among the state, market, and stockizens, s.I.: Arizona State University.

Khairan, K., 2016. Ex-Repco head jailed 5 years, fined RM5m. Kuala Lumpur: New Straits Times.

Koon, C. P., 2004. Repco seeks potential white knights. Business Times, 1 April, p. 5.

Manne, H. G., 1966. Defense of insider trading. Harvard Business Review, 44(6), pp. 113-122.

Nambiar, P., 2007. SC files suit against FTEC boss. New Straits Times, 2 October, p. 37.

New Straits Times, 2005. Datuk in the dock. 27 June, p. 01.

New Straits Times, 2006. MD charged with lying to the SC. 10 February, p. 4.

Oh, E., 2015. War against insider trading goes to court. The Star Online, 12 December .

Putnins, T. J., 2012. Market manipulation: a survey. Journal of Economic Surveys, 26(5), pp. 952-967.

Raj, A. P., 2004. Shares of FTEC suspended after hitting limit-down. Business Times, 16 January.

Securities Commission Malaysia, 2012. Malaysia code of corporate governance, Kuala Lumpur:

Securities Commission Malaysia.

Securities Commission Malaysia, 2015. Capital markets and services act 2007, amendment 2015.

Kuala Lumpur: Securities Commission Malaysia.

Securities Commission Malaysia, 2016. Enforcement related press releases. [Online]

Available at: http://www.sc.com.my/enforcement/enforcement-related-press-releases/

[Accessed 10 December 2016].

Tam, F., 2004. Interesting trading trends in Maica, FTEC. Business Times, 26 January.

White, M. \& Marsh, E., 2006. Content analysis: A flexible methodology. Library Trends, 55(1), pp. 2245. 
Wirama, D. G., Wiksuana, I. G. B., Mohd-Sanusi, Z. \& Kazemian, S., 2017. Price manipulation by dissemination of rumors: evidence from the Indonesia stock market. International Journal of Economics and Finanical Issues, 7(1), pp. 429-434.

Wynn, J. \& Williams, C., 2012. Principles for conducting critical realist case study research in information systems. MIS Quarterly, 36(3), pp. 787-810.

Yin, R. K., 2003. Case study research, design and methods. 3rd ed. Thousand Oaks: Sage.

Zaidi, I. I., 2007. FTEC Resources chief and founder resigns. New Straits Times, 3 October, p. 41. 